\title{
An outline economic strategy for Indonesia to sustainably meet its electricity and carbon emissions targets
}

\author{
Uswatun HASANAH
}

Universitas Indonesia, Indonesia

Les DUCKERS

Coventry University, UK

\begin{abstract}
:
Aim: In this paper we demonstrate an outline strategy for Indonesia to move its electrical generation from fossil fuels to renewable sources in order to reduce carbon dioxide emissions whilst avoiding excessive costs. The modelling here is based on assumed present fossil fuel generating plants.
\end{abstract}

Design / Research methods: We have modelled a representative electrical generation system based on burning coal, oil and gas, and by replacing retiring stations with photovoltaic cells and wind turbines we have considered the cost and carbon dioxide implications over a 30 year period. Additionally the modelling is extended to increasing the Indonesian installed electrical capacity.

Conclusions / findings: The results show that Indonesia could meet its carbon dioxide emission reduction targets in an economic way by a phased strategy of introducing renewable energy sources. These results are preliminary and will be refined in a future article where we will include the detail of actual existing power stations, with their capacity and anticipated end of life date.

Originality / values of the article: There has been, and continues to be, a general resistance to the adoption of renewable energy. This paper shows the economic benefit that accompanies carbon dioxide reduction, and thus brings a new aspect to the consideration of carbon reduction,

Implications of the research: Indonesia faces difficulties in providing electricity whilst meeting its climate change obligations. This research points to a viable economic strategy which may not only meet those obligations, but actually increase electrical provision across the country.

Key words: Sustainable development, climate change, carbon emissions, renewable energy

JEL: C51, L94, Q01, Q42

Contact details: Les Duckers, Coventry University, UK, E-mail: L.Duckers@ coventry.ac.uk. Received: 16.03.2018, Revised: 30.10.2018, Accepted: 30.10.2018.

doi: http://dx.doi.org/10.29015/cerem.696 


\section{Introduction}

The current use of conventional energy. Indonesia has a particularly difficult challenge of providing low carbon energy, particularly in the electricity sector, due to its geographical, demographical and socio-economic factors. Reserves of oil and gas, are being rapidly depleted, making Indonesia's energy security weak as she has to import both oil and gas. Because electrical power generation is dominated by coal, gas and oil and takes the substantial portion of the national oil subsidy, a strategy to shift from fossil fuels to renewable energy is necessary. With much lower green-house gas emissions, renewable energy sources will also help Indonesia to fulfil its carbon emission reduction target.

Having a population of around 264 million in 2017 spread across 17,500 islands has placed Indonesia as the 4 th most populous in the world. In addition, according to the United Nations Convention on the Law of the Sea (UNCLOS) meeting on August 2017, this archipelagic country is the 7th largest country by sea and land area.

The rapidly growing oil demand coupled with the continued decrease of oil production has placed Indonesia as net oil importer country since 2004. The falling oil production might be caused by the limited investment in new oil exploration and the lack of rejuvenation of existing oil sites. Although a founding member of OPEC, the geopolitical factors and the fluctuating world oil situation forced Indonesia to make a strategic decision to suspend its OPEC membership in January 2009 (see Figure 1). However, Indonesia re-joined OPEC in 2014 although still been bearing the status of a net oil importer (BP Statistical Review of World Energy 2015). 

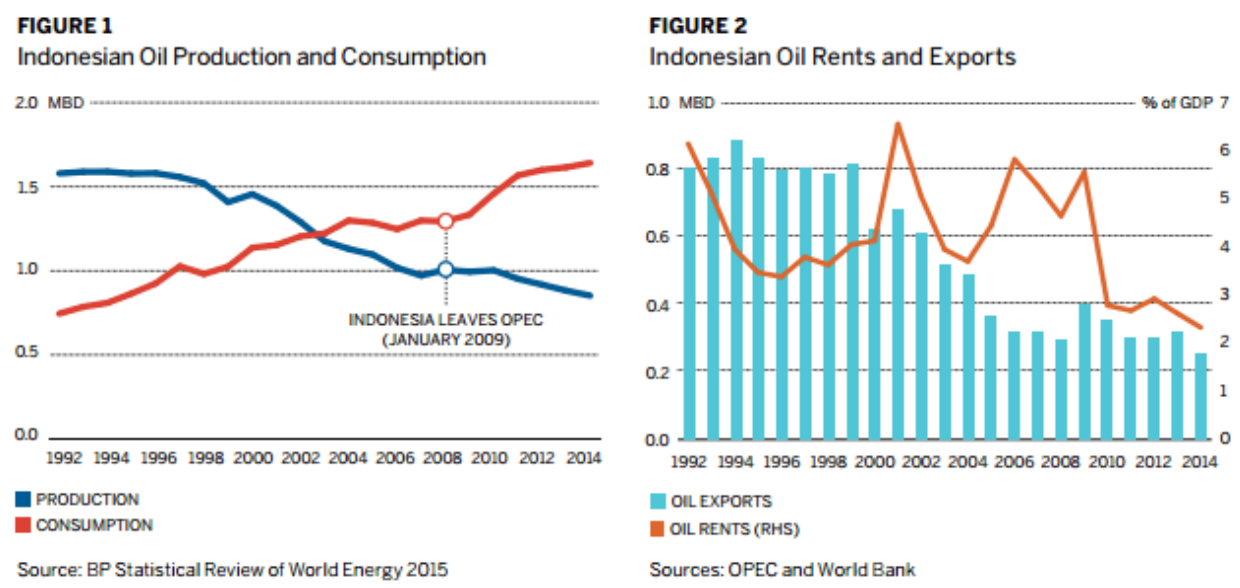

Less than a year after re-joining OPEC, Indonesia reconsidered its membership in OPEC due to the internal pressure to limit oil production for OPEC members. In this case, Indonesia would cut the oil production by 5,000 barrels per day (bpd) instead of 37,000 bpd required by OPEC. This disagreement forced Indonesia to leave OPEC for the second time. In regards to oil exports, the gradual decrease in oil rents ${ }^{1}$ and exports can be seen in Figure 2.

Besides being a net oil importer, Indonesia could follow a similar story for liquefied natural gas (LNG), becoming a net $\mathrm{LNG}$ importer in the next ten years or less. At this time, Indonesia is still a net LNG exporter and ranks $5^{\text {th }}$ highest in the world for LNG exports with 16.6 million tons/year and a market share of $6.4 \%$ (IHS Market, IGU 2017). Nonetheless, Indonesia is projected to be net LNG importer by 2022. In regards to net importer/exporter status, Figure 3 and Figure 4 shows the Indonesian position in ASEAN and in the World. The projections show Indonesia becoming more dependent on oil and gas imports and thus more vulnerable to World prices.

\footnotetext{
${ }^{1}$ By definition, oil rents reflect the difference between the world price of oil production and total costs of production. Each country in Asia has diverse oil rents value as \% of its GDP. It is estimated based on sources and methods described in "The Changing Wealth of Nations: Measuring Sustainable Development in the New Millennium” (World Bank 2011).
} 
Figure 3. Net oil and gas imports as a share of demand ${ }^{2}$

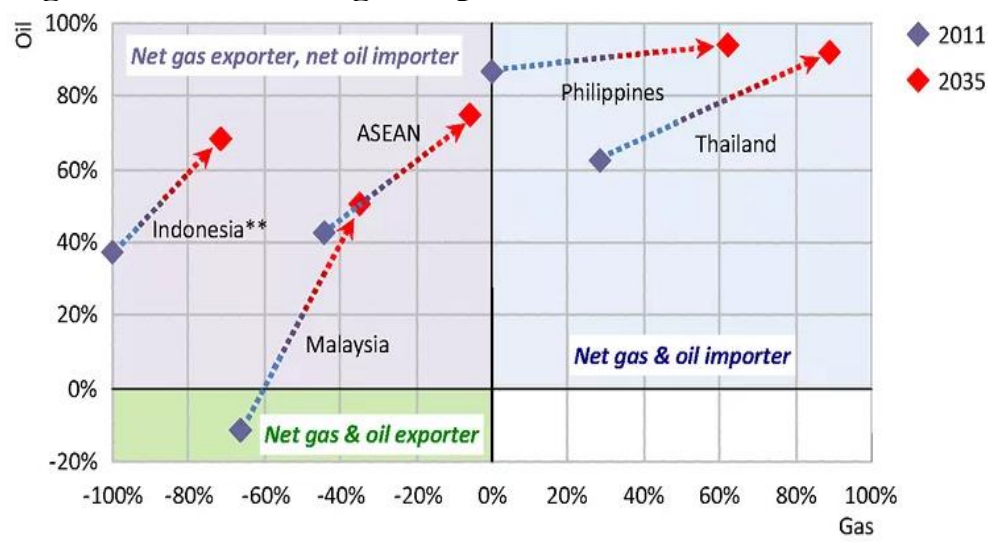

Source: Authors' own elaboration based on WEO (2013).

Figure 4. Net oil and gas imports/exports shares in selected regions in the New Policies Scenario

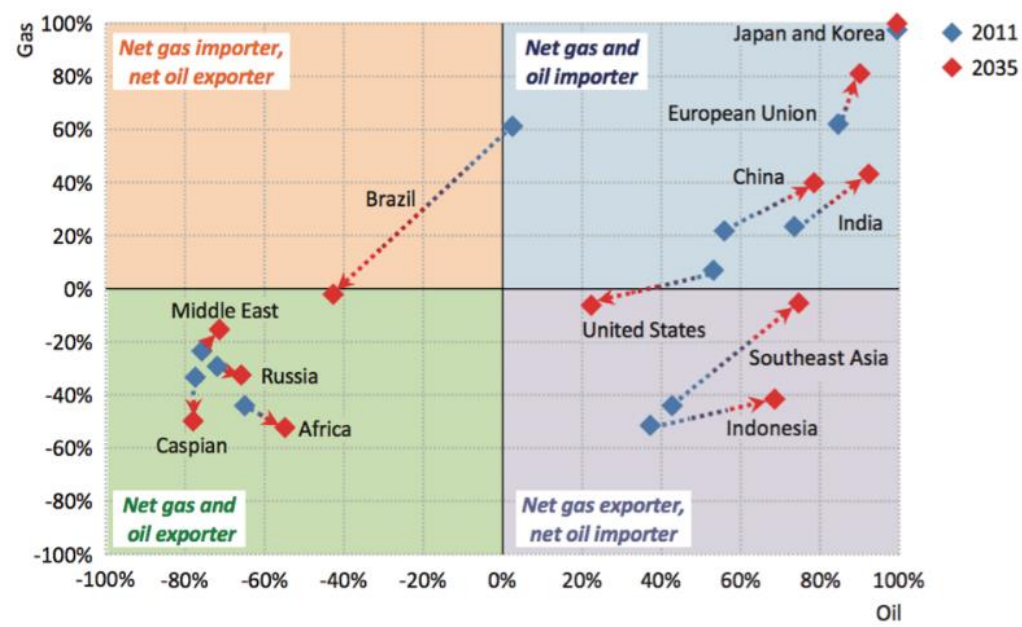

Source: Authors' own elaboration based on WEO (2013).

In regards to coal, Indonesia is the $5^{\text {th }}$ highest rank in the World, after China, USA, Australia and India, with an annual production of 255.7 million tons oil equivalent (MTOE) (BP Statistics 2017). Since Indonesia has targeted greenhouse

\footnotetext{
${ }^{2}$ Import shares for each fuel are calculated as net imports divided by primary demand while export shares is net exports divided by production. A negative number indicates net exports. Southeast Asia covers ASEAN region, includes Indonesia.
} 
gas emission reduction, up to now, using coal as a source of electricity generation has been highly contentious. On one hand, using coal as power generation is considered more practical because Indonesia has abundant coal coupled with low production costs. It is argued that coal in Indonesia is relatively "clean" because it is has a low (0.1 to $1 \%$ ) sulphur content and is processed using clean coal technologies. The development of coalbed methane (CBM) reservoirs at the upstream side has attracted many players recently. In addition, though renewable energy resources have been promoted to help meet emission reduction targets, there is no clear indication for the significant reduction of coal utilization in the foreseeable future. Moreover, global markets still demand a substantial amount of coal which Indonesia exports at around 70-80 \% of its coal production. Indonesian coal commands a relatively high price. In regards to mid-long term national energy planning, according to the Ministry of Energy and Mineral Resources (2016) coal will contribute about $30 \%$ to the energy mix in 2025; 6\% higher than in 2011. This is in contradiction with Indonesia ratifying the Paris Agreement on carbon emission reduction at the substantial level of $29 \%$ by 2030 .

The commitment to climate change reduction (COP21). The Paris Accord (COP21) gained support from around 197 countries in December 2015, and these countries have ratified their commitment to the Accord and will act to restrict the increase in average surface temperature of the World to $1.5 \mathrm{C}$. This is regarded as a vital target as it is a tipping point beyond which we may not be able to stabilize the World climate. Notably, US President Trump has withdrawn the US from COP21. The commitment to reduce carbon emission about $29 \%$ by 2030 has forced Indonesia to plan for the deployment of low carbon energy. The increase of coal in Indonesia's energy mix 2025 is therefore a paradoxical policy, with unclear strategies in each Ministry and among Ministeries to achieve the emission reduction target.

Electricity provision. Indonesia has strived for more sustainable and environmentally benign energy in recent years. The commitment can be seen in Indonesia's energy mix 2025 in comparison with 2011. By setting the substantial increase in the renewable energy share to $26 \%$ by 2025 in contrast with $6 \%$ in 2011 , the government has demanded a substantial growth in renewable energy 
deployment. Unfortunately, the acceleration for renewable energy deployment, particularly electricity generation, is not as fast as the "written" plan. The growing pressure over the use of clean energy has pushed Indonesia to reduce its power generation from coal, according to Ministry of Energy and Mineral Resources,

The current picture of electricity (Cornot-Gandolphe 2017): About 89\% of electricity is provided by fossil fuels and the rest from hydro and geothermal. In 2010 only $68 \%$ of the population had access to electricity, by 2014 this number had risen to $84 \%$. This means that people living on many of the islands still have no access to electricity. Meanwhile, the growth in demand (at $7.1 \%$ per year since 2010) for electricity continues to strain the existing network. Power capacity has doubled in the past decade from $27 \mathrm{GW}$ to $55.5 \mathrm{GW}$ at the end of 2015 . Coal is the largest contributor at $56 \%$, and possibly growing, whereas the government's policy to phase out the use of oil has seen a reduction in the consumption of diesel.

In this paper we demonstrate an outline strategy for Indonesia to move its electrical generation from fossil fuels to renewable sources in order to reduce carbon dioxide emissions whilst avoiding excessive costs. The modelling here is based on assumed present fossil fuel generating plants.

\section{Options for replacing fossil fuels}

This paper examines the options for both replacing and augmenting Indonesia's existing power stations. We look at the economics of operating each power plant to its end of life and then replacing its capacity with a renewable low carbon power plant selected from PV, wind, biomass, wave or hydro.

Nuclear. Nuclear and renewable energy technologies are "low carbon" energy sources which release much less carbon dioxide per kWh than fossil fuels. However, nuclear sources are potentially dangerous because of the radioactivity associated with their operation, decommissioning and waste management. Beyond this, the cost of new build nuclear power stations is proving to be much higher than renewable sources. Hinckley Point $\mathrm{C}$ in the UK is under construction by a consortium led by EDF (Electricite de France). The UK Government has guaranteed the consortium 
$£ 92.5 / \mathrm{MWh}$ (US\$120/MWh) for 35 years. This is about twice the current cost of UK electricity, and the predictions about the cost of renewables suggest that by the time that Hinckley Point C is commissioned in 2027 this guarantee will be several times higher than the unit cost of PV or wind generated electricity.

Photovoltaic. Photovoltaic (PV) electricity is generated by converting solar energy into Direct Current (dc) electricity. This dc electricity can be stored in batteries and then converted into Alternating Current (ac) electricity by passing it through an inverter. In this case, Indonesia enjoys high solar insolation and so is an ideal candidate for exploiting PV technology. An obvious problem is the lack of output during the night and periods of low sunlight. To some extent the batteries can alleviate this difficulty.

Wind. Wind-generated electricity is produced by wind turbines of various sizes. Some wind turbines are small and can cater for a small remote community by generating a few kilo-Watts $(\mathrm{kW})$ of electricity A recent development is extremely large diameter two-bladed rotors mounted on a high tower, which can produce multi Mega-Watts (MW) ac outputs. As with PV, wind turbines offer a good option for Indonesia across its numerous islands, but with the obvious difficulty of the intermittency of wind.

Others. Other renewables include tidal, hydro, wave and biomass, but in general geothermal, PV and wind are the most immediately viable technologies for Indonesia, with these others potentially contributing on some islands in the future.

\section{Economic considerations}

The range of cost of electricity generation from renewable and conventional energy sources can be seen in Table 1 . There are some advantages by applying the model of the levelized cost of energy (LCOE) because this model provides us the net present value (NPV) of the (total) costs divided by the amount of energy generated in the whole life cycle of the project. Table 1 is taken from the $10^{\text {th }}$ annual review of electricity costs (Lazard 2016), which clearly shows the lowest range of costs are 
available from wind technology. These costs are based on US technology and conditions.

Table 1. Levelized cost of electricity generated from various sources

\begin{tabular}{|c|c|c|c|c|c|c|}
\hline \multirow[t]{2}{*}{ Renewable Energy } & \multicolumn{2}{|c|}{$\begin{array}{c}\text { Cost } \\
\text { US\$/MWh }\end{array}$} & • & \multirow[t]{2}{*}{$\begin{array}{l}\text { Conventional } \\
\text { Energy }\end{array}$} & \multicolumn{2}{|c|}{ Cost US\$/MWh } \\
\hline & Min & Max & & & Min & Max \\
\hline Solar PV residential & 138 & 222 & & & & \\
\hline $\begin{array}{l}\text { Solar PV Rooftop } \\
\text { C\&I }\end{array}$ & 88 & 193 & & Diesel ICE & 212 & 281 \\
\hline $\begin{array}{l}\text { Solar } \\
\text { Community }\end{array}$ & 78 & 135 & & Gas ICE & 68 & 101 \\
\hline $\begin{array}{l}\text { PV crystalline } \\
\text { utility }\end{array}$ & 49 & 61 & & Gas Peaking & 165 & 217 \\
\hline PV thin film utility & 46 & 56 & & Nuclear & 97 & 136 \\
\hline Biomass & 77 & 110 & & Coal & 60 & 143 \\
\hline Microturbine & 76 & 89 & & Gas CC & 48 & 78 \\
\hline Geothermal & 79 & 117 & & & & \\
\hline Wind & 32 & 62 & & & & \\
\hline
\end{tabular}

Sources: Lazard (2016).

Although PV requires substantial capital costs, resulting in high levelized costs, this source stills looks attractive. Lazard (2016) reports that the costs of PV and wind have been falling for ten years, and can be expected to continue to drop as maturing technologies become more efficient, and as mass production reduces manufacturing costs. Figure 5 shows the reduction in costs for PV falls by $20 \%$ for each doubling of installed capacity. However, the intermittency of both solar and wind resources creates problems with the grid, which Lazard states will require the continued employment of some fossil fuel power stations to meet the demand in the absence of PV or wind. 
Figure 5. Historical development of the cost of PV modules

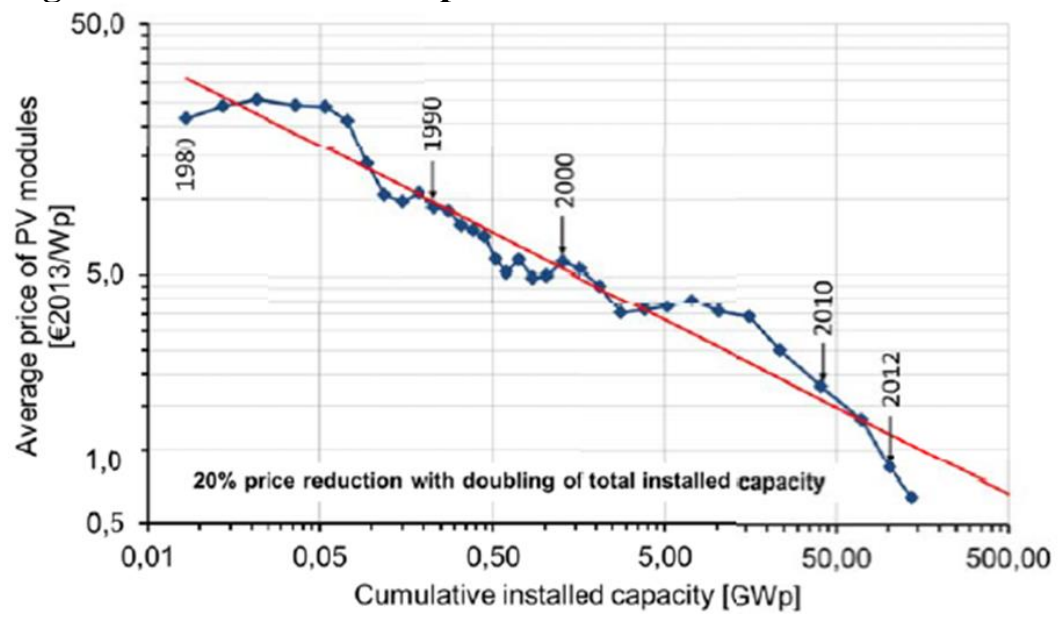

Source: Authors' own elaboration based on Fraunhofer Institute (2016).

\section{Economics of intermittency}

Alternatives to retaining fossil fuel power stations on the grid are to use smart grids to match supply to demand and/or to include energy storage. In fact, energy storage is essential where PV or wind are the energy providers.

Figure 6. Example of wind speed and associated instantaneous power against time

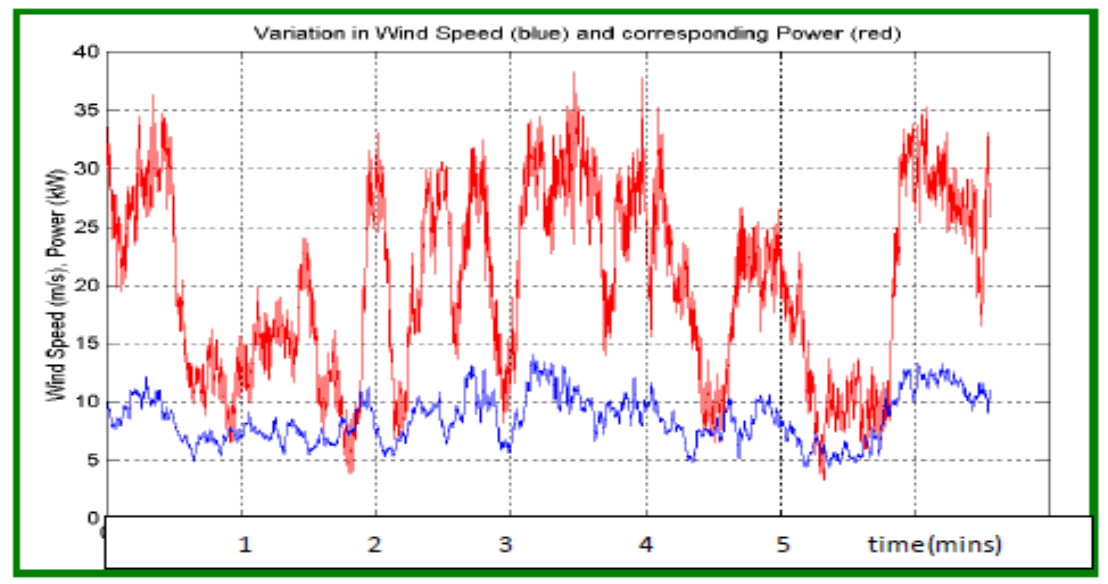

Source: Authors' own elaboration. 
To illustrate this, consider Figure 6, where the wind speed varies quite extensively over a period of a few minutes. The output from a wind turbine is related to the cube of wind speed and so the power output varies by a factor of 7:1 during the few minutes of the record. Short term battery storage over minutes can help to smooth this power output. In order to meet the demand over a 24 hours period, longterm battery storage can be used. The energy storage developers in the U.S. installed $336 \mathrm{MWh}$ of storage in 2016, double the amount from the previous year. This means that about $3 \%$ of the US daily electricity generated could be stored. By 2022, US energy storage installations are expected to reach 7,300 $\mathrm{MWh}$, capable of storing $65 \%$ of the daily electrical generation, and generating annual revenues of $\$ 3.3$ billion. The technical value of such storage is that it supports and thus permits reliance on variable inputs from renewables such as wind and PV. Lithium-ion batteries made up 98.4 percent of the U.S. energy storage market in the last quarter of 2016. Lithium-ion battery prices have fallen $73 \%$ since 2010, due to improvements in technology and scaling by manufacturers. Battery prices as a whole have declined 40 percent since 2014 (Greene, Barrow 2017). In this paper, though, we have not included additional energy storage beyond that incorporated into PV systems. In the first 15 years of the modelling this is reasonable because we will retain a major contribution from fossil fuels, which provide inherent storage. In a future paper we will model more rapid adoption of renewables and therefore will address the storage question in more detail.

\section{Methodology}

In this research, we assume that the present electrical generation in Indonesia comes from gas, coal and oil fueled plants in equal numbers, as this reasonably represents the cost and emissions from the power stations in Indonesia. Further, we assume that due to their different ages that they are due for decommissioning at various dates over the next 30 years. We have taken a typical installed capacity of 800MW for each of these plants to demonstrate the feasibility of a GHG reduction strategy. We will introduce more detail of generating plant capacities, costs, 
emissions and scheduled end of life in subsequent modelling and a future paper. In this modeling we have used the US cost data from Lazard (2016), capacity factor, greenhouse gas emissions, as $\mathrm{CO}_{2} \mathrm{eq}$ and cost of the energy sources are given in table 2. Note that the low capacity factors for wind and PV reflect the reliance of these sources on the intermittent availability of wind and sun, whereas the other energy sources are limited only by technical aspects of their operations such as repair and maintenance periods, and so have capacity factors close to 1 (or 100\%).

Table 2. Energy source (fossil and renewable), capacity factor, greenhouse gas emissions, and cost

\begin{tabular}{|l|c|c|c|}
\hline \multirow{2}{*}{ Energy Source } & capacity factor & $\mathrm{CO}_{2}$ eq T/MWh & \$/MWh \\
\hline gas & 0.9 & 0.4 & 85 \\
\hline coal & 0.85 & 1 & 105 \\
\hline oil & 0.8 & 0.85 & 120 \\
\hline PV & 0.25 & 0.02 & 55 \\
\hline wind & 0.3 & 0.02 & 47 \\
\hline biomass & 0.9 & 0.02 & 94 \\
\hline hydro & 0.7 & 0.02 & 83 \\
\hline
\end{tabular}

Source: Lazard (2016).

\section{Modelling a strategy for Indonesia}

We suggest a conversion strategy from fossil fuels to renewable over a period of 30 years to 2050. This relies on continuing operation of fossil fuel power stations until each one reaches its scheduled end of life, or earlier if the economics and climate change gas emissions are improved. On the other hand, gradual investment in primarily PV and wind farms replace those decommissioned fossil fuel plants. We present three scenarios.

A) Business as usual (BAU), in which only fossil fuel plants are used into the future, and are replaced by new fossil fuel plants when necessary.

B) Matching decommissioned fossil fuel plants with PV, wind farms, biomass and hydro. 
C) An expansion of the Indonesian electricity provision by adding more PV and wind than in scenario $B$.

Results

A) Scenario Business as usual

Figure 7. (A) annual output

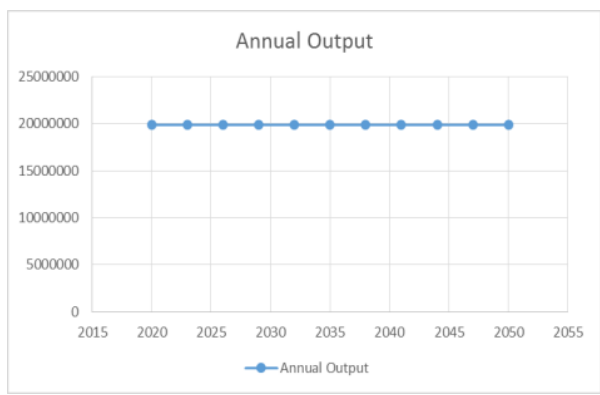

Source: Authors' own elaboration
Figure 8. (A) $\mathrm{CO}_{2}$ emissions

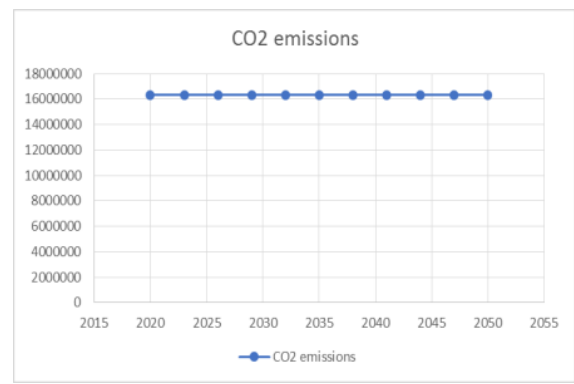

The BAU scenario shows a constant annual output and $\mathrm{CO} 2$ emissions

B) Matching decommissioned fossil fuel plants with PV and wind farms

Figure 9. (B) Output

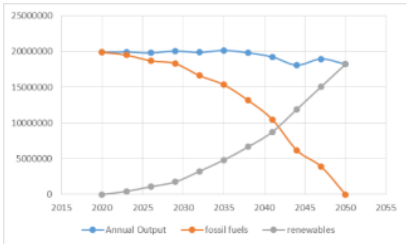

Figure 10. (B) $\mathrm{CO}_{2}$

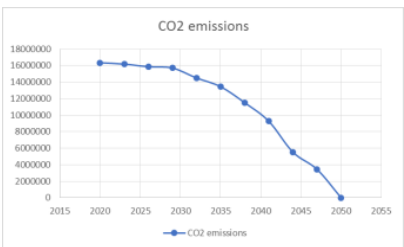

Figure 11. (B) Cost

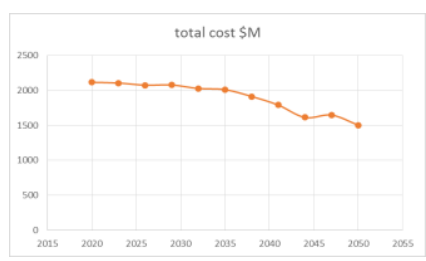

Source: Authors' own elaboration

By introducing PV and wind to replace obsolete or retired fossil fuel plant the $\mathrm{CO}_{2}$ emissions can be reduced to near zero by 2050 , whilst the total cost of energy falls by about $30 \%$ over the same period. 
C) An expansion of the Indonesian electricity provision

Figure 12. (C) Output Figure 13. (C) $\mathrm{CO}_{2}$

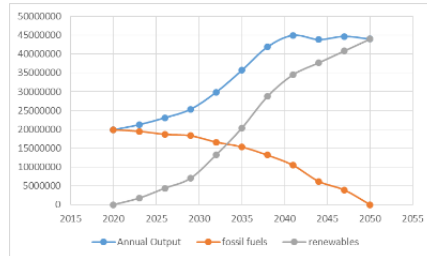

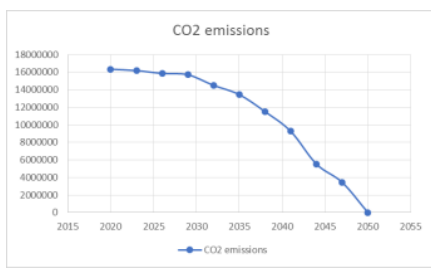

Figure 14. (C) Cost

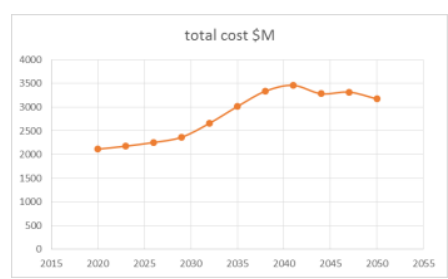

Source: Authors' own elaboration

By more than simply replacing fossil fuel plants with renewable capacity, this scenario shows a $125 \%$ increase in electricity capacity and a near zero $\mathrm{CO}_{2}$ emission over 30 years period. The total cost increased by only $66 \%$.

The third scenario could be made more representative by including the falling cost of renewables. For example, there is evidence that PV costs drop by $20 \%$ each time the installed capacity doubles. Thus, the average electricity cost will approximately half by 2050 . Figure 15 shows scenario C) as calculated above and with the cost of $\mathrm{PV}$ reducing due to improved performance efficiency and production efficiency.

Figure 15. The average cost of electricity in scenario (C)

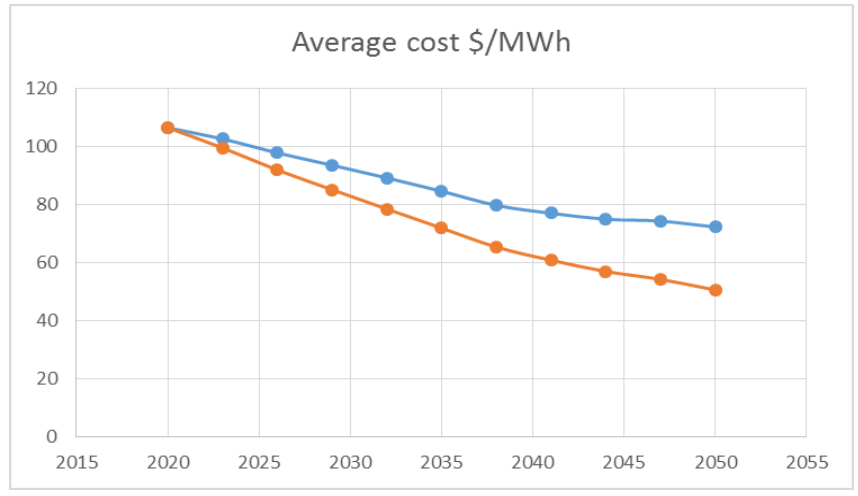

Source: Authors' own elaboration

Note: The lower curve assumes a falling PV cost 


\section{Uswatun HASANAH, Les DUCKERS}

We have not made any provision here for the cost of storage to smooth out the delivered electricity over short periods or to match output to demand. It is conceivable that individual houses fit PV panels, or have wind turbines, or have storage batteries, whilst being connected to the grid. On the other hand, renewables are extremely suitable for dispersed deployment. A community could install its own small grid together with storage. Thus, providing electricity on previously unconnected islands would not require extension of the national grid.

\section{Conclusion}

Indonesia can meet its commitment to COP21 by adopting a strategy of gradually replacing its fossil fuel generating power plants with PV and wind farms. This modeling suggests that the total annual cost of electricity provision will be reduced. On the other hand, by spending $66 \%$ more, the expansion scenario suggests that the electricity capacity would be increased by $125 \%$.

\section{References}

Arshad A. (2016), Indonesia's Parliament ratifies Paris Agreement on Climate Change, The Straits Times, http://www.straitstimes.com/asia/se-asia/indonesias-parliament-ratifies-parisagreement-on-climate-change [15.08.2017].

BP Statistical Review of World Energy 2015 (2015), https://www.bp.com/content/dam/bpcountry/es_es/spain/documents/downloads/PDF/bp-statistical-review-of-world-energy-2015full-report.pdf.

Chevron (2017), The world depends on natural gas, World LNG Report 2017 edition, International Gas Union (IGU), https://www.igu.org/sites/default/files/103419World_IGU_Report_no\%20crops.pdf [15.08.2017].

Cornot-Gandolphe S (2017), Indonesia's electricity demand and the coal sector. Export or meet domestic demand?, The Oxford Institute for Energy Studies OIES paper CL5, https://www.oxfordenergy.org/wpcms/wp-content/uploads/2017/03/Indonesias-ElectricityDemand-and-the-Coal-Sector-Export-or-meet-domestic-demand-CL-5.pdf [07.12.2018]. 
Fraunhofer Institute (2016), Photovoltaics Report 2016, Fraunhofer Institute for Solar Energy Systems, ISE with support of PSE AG Freiburg, www.ise.fraunhofer.de [01.03.2018].

Green B.C., Barrow D.M. (2017), Financing energy storage projects. Assessing risks - part one, http://www.renewableenergyworld.com/articles/2017/07/financing-energy-storageprojects-assessing-risks-part-one.html [21.09.2018].

Index Mundi (2017), Oil rents (\% of GDP) - Asia, https://www.indexmundi.com/facts/indicators/NY.GDP.PETR.RT.ZS/map/asia [15.08.2017].

Indonesia Investments (2017a), How many islands does Indonesia have? Government to count, https://www.indonesia-investments.com/news/todays-headlines/how-many-islandsdoes-indonesia-have-government-to-count/item7898? [15.08.2017].

Indonesia Investments (2017b), Coal, https://www.indonesiainvestments.com/business/commodities/coal/item236? [15.08.2017].

Indonesia Population (2017), Worldometers. Population, http://www.worldometers.info/world-population/indonesia-population/ [15.08.2017].

Jaquith C. (2016), Levelized cost of energy analysis 10.0, https://www.lazard.com/perspective/levelized-cost-of-energy-analysis-100/ [15.08.2017].

Jensen F., Asmarini W. (2016), Net oil importer Indonesia leaves producer club OPEC, again, https://www.reuters.com/article/us-opec-meeting-indonesia/net-oil-importerindonesia-leaves-producer-club-opec-again-idUSKBN13Q3M7 [15.08.2017].

Lazard (2016) Levelised cost of energy 10th report, https://www.lazard.com/perspective/levelized-cost-of-energy-analysis-100/ [07.12.2018].

OPEC (2015), Welcome back, Indonesia! OPEC bulletin commentary, http://www.opec.org/opec_web/en/press_room/3403.htm [15.08.2018].

Singgih V.P. (2017), Indonesia projected to become net LNG importer by 2022, The Jakarta Post, http://www.thejakartapost.com/news/2017/05/29/indonesia-projected-to-become-netlong-importer-by-2022.html [15.08.2017].

Van Noordwijk M. et al. (2014), Reducing emissions from land use in Indonesia. Motivation, policy instruments, and expected funding streams, „Mitigation and Adoption Strategies for Global Change", vol. 19 no. 6, pp. 677-692.

WEO (2013), Special report. Southeast Asia energy outlook, International Energy Agency (IEA), https://webstore.iea.org/weo-2013-special-report-southeast-asia-energy-outlook [07.12.2018]. 


\section{Uswatun HASANAH, Les DUCKERS}

World Bank (2011), The changing wealth of nations. Measuring sustainable development in the New Millennium. Environment and Development, https://openknowledge.worldbank.org/handle/10986/2252 [15.08.2017]. 